\title{
Developmental expression and hormonal regulation of glucocorticoid and thyroid hormone receptors during metamorphosis in Xenopus laevis
}

\author{
L P Krain and R J Denver \\ Department of Molecular, Cellular and Developmental Biology, The University of Michigan, Ann Arbor, Michigan 48109, USA \\ (Requests for offprints should be addressed to R J Denver, Department of Molecular, Cellular and Developmental Biology, 3065C Natural Science Building, \\ The University of Michigan, Ann Arbor, Michigan 48109-1048, USA; Email: rdenver@umich.edu) \\ (L P Krain is currently at University of Michigan Hospital, Psychiatry, 9D UH 9812, Ann Arbor, Michigan 48109-0120, USA)
}

\begin{abstract}
Corticosteroids, the primary circulating vertebrate stress hormones, are known to potentiate the actions of thyroid hormone in amphibian metamorphosis. Environmental modulation of the production of stress hormones may be one way that tadpoles respond to variation in their larval habitat, and thus control the timing of metamorphosis. Thyroid hormone and corticosteroids act through structurally similar nuclear receptors, and interactions at the transcriptional level could lead to regulation of common pathways controlling metamorphosis. To better understand the roles of corticosteroids in amphibian metamorphosis we analyzed the developmental and hormonedependent expression of glucocorticoid receptor (GR) mRNA in the brain (diencephalon), intestine and tail of Xenopus laevis tadpoles. We compared the expression patterns of GR with expression of thyroid hormone receptor beta $(\operatorname{TR} \beta)$. In an effort to determine the relationship between nuclear hormone receptor expression and levels of ligand, we also analyzed changes in wholebody content of 3,5,3'-triiodothyronine $\left(\mathrm{T}_{3}\right)$, thyroxine, and corticosterone (CORT). GR transcripts of 8,4 and $2 \mathrm{~kb}$ were detected in all tadpole tissues, but only the 4 and $2 \mathrm{~kb}$ transcripts could be detected in embryos. The level of GR mRNA was low during premetamorphosis in the
\end{abstract}

brain but increased significantly during prometamorphosis, remained at a constant level throughout metamorphosis, and increased to its highest level in the juvenile frog. GR mRNA level in the intestine remained relatively constant, but increased in the tail throughout metamorphosis, reaching a maximum at metamorphic climax. The level of GR mRNA was increased by treatment with CORT in the intestine but not in the brain or tail. TR $\beta$ mRNA level increased in the brain, intestine and tail during metamorphosis and was induced by treatment with $\mathrm{T}_{3}$. Analysis of possible crossregulatory relationships between GRs and TRs showed that GR mRNA was upregulated by exogenous $T_{3}(50 \mathrm{nM})$ in the tail but downregulated in the brain of premetamorphic tadpoles. Exogenous CORT $(100 \mathrm{nM})$ upregulated TR $\beta$ mRNA in the intestine. Our findings provide evidence for tissuespecific positive, negative and crossregulation of nuclear hormone receptors during metamorphosis of $X$. laevis. The synergy of CORT with $\mathrm{T}_{3}$ on tadpole tail resorption may depend on the accelerated accumulation of GR transcripts in this tissue during metamorphosis, which may be driven by rising plasma thyroid hormone titers.

Journal of Endocrinology (2004) 181, 91-104

\section{Introduction}

The primary morphogen controlling amphibian metamorphosis is thyroid hormone, which regulates gene transcription by binding to proteins that are members of the nuclear receptor superfamily (Shi 2000). Two genes designated alpha and beta code for thyroid hormone receptors (TRs) in vertebrates (Forrest 1994, Mangelsdorf et al. 1995). In Xenopus laevis, TR $\alpha$ mRNA increases shortly after hatching and remains relatively constant throughout the larval period and metamorphosis (Yaoita \& Brown 1990). By contrast, TR $\beta$ expression is low during premetamorphosis before the acceleration of thyroid activity, but then increases dramatically throughout prometamorphosis, reaching a maximum at metamorphic climax (Yaoita \& Brown 1990). The expression of TR $\beta$ in X. laevis is induced by thyroid hormone (i.e. it is autoinduced; Tata 1994) and the X. laevis TR $\beta$ gene contains at least one functional thyroid hormone response element in the proximal promoter region (reviewed by Shi 2000).

Corticosteroids produced by the interrenal glands (amphibian homologue of the mammalian adrenal cortex) are implicated in the positive control of metamorphosis (Kikuyama et al. 1993, Hayes 1997). Corticosteroids, like 
thyroid hormone, regulate gene transcription by binding to nuclear receptors. Plasma corticosteroid concentrations rise markedly during metamorphic climax in several anuran species (Jaffe 1981, Krug et al. 1983, Jolivet-Jaudet \& Leloup-Hatey 1984, Kikuyama et al. 1986) and in the urodele Ambystoma tigrinum (Carr \& Norris 1988). This rise in plasma corticosteroids is largely synchronous with the rise in thyroid hormone production (Kikuyama et al. 1993, Denver 1998). Several investigators have shown that corticosteroids can synergize with thyroid hormone to accelerate tadpole metamorphosis (see Kikuyama et al. 1993, Hayes 1997) and at least two mechanisms have been proposed for this effect. For example, treatment with corticosteroids increases nuclear 3,5,3'-triiodothyronine $\left(\mathrm{T}_{3}\right)$ binding capacity in tailfin of two anuran species (Niki et al. 1981, Suzuki \& Kikuyama 1983b). Another mode of action may be through the regulation of tissue deiodinases, where corticosteroids can enhance conversion of thyroxine $\left(T_{4}\right)$ to $T_{3}$, the more biologically active hormone, and decrease the degradation of $T_{3}$ (Galton 1990).

There is biochemical evidence for the presence of corticosteroid receptors in tadpole tissues (reviewed by Kikuyama et al. 1993) but there are currently no data on the expression or hormonal regulation of corticosteroid receptor genes during metamorphosis. Gao et al. (1994) isolated a cDNA for the $X$. laevis glucocorticoid receptor (GR) and showed, using Northern blot analysis, that the gene is first expressed during late embryogenesis; however, they did not analyze GR expression during metamorphosis. Csikos et al. (1995) isolated partial cDNA clones for a putative $X$. laevis mineralocorticoid receptor (MR). They detected a low level of MR mRNA in whole tadpoles at Nieuwkoop and Faber (NF) stage 60 (Nieuwkoop \& Faber 1956) by an RNase protection assay, but were unable to detect MR transcripts by Northern blotting (we are also unable to detect MR mRNA in $X$. laevis tadpoles by Northern blotting, R J Denver, unpublished observations).

In the present study we analyzed the developmental and hormone-dependent expression of mRNA for the X. laevis GR in three tissues (brain, intestine and tail), and compared this with expression patterns of TR $\beta$. The level of GR mRNA in tadpole brain (the region of the diencephalon) was low during premetamorphosis, rose during prometamorphosis and then again in the juvenile frog. GR gene expression was strongly increased in tail throughout prometamorphosis and metamorphic climax. We found that positive or negative regulation by the respective ligand, or crossregulation of nuclear hormone receptor gene expression was tissue-specific. While TR $\beta$ was upregulated by its ligand in all three tissues examined, corticosterone (CORT) increased GR mRNA only in the intestine. Crossregulation studies showed that GR mRNA is negatively (brain) or positively (tail) regulated by exogenous $T_{3}$, and $\operatorname{TR} \beta$ is upregulated by CORT in tadpole intestine. Our results also show that tadpoles concentrate $T_{3}$ from the environment, resulting in tissue concentrations of the hormone that are 4-6 times the environmental concentration. We discuss the implications of these findings for doses of $\mathrm{T}_{3}$ commonly used to induce $X$. laevis metamorphosis.

\section{Materials and Methods}

\section{Animals and hormone treatments}

We obtained adult X. laevis from Xenopus I (Dexter, MI, USA) and spawned them in the laboratory by injecting into the dorsal lymph sac $1 \mu \mathrm{g}$ gonadotropin-releasing hormone agonist ([des-Gly $\left.{ }^{10}, \mathrm{D}-\mathrm{His}(\mathrm{Bzl})^{6}\right]-\mathrm{LH}-\mathrm{RH}$ ethylamide; Sigma Chemical Co., St Louis, MO, USA). We reared tadpoles at $21-23{ }^{\circ} \mathrm{C}$ on a $12 \mathrm{~h}$ light: $12 \mathrm{~h}$ darkness photoperiod in charcoal-purified, $\mathrm{pH}$-adjusted water and fed them a suspension of pulverized rabbit chow. Hormones were added directly to the aquarium water. $\mathrm{T}_{3}$ was dissolved in a small volume of $0.01 \mathrm{M} \mathrm{NaOH}$ and diluted 100 -fold in $0.6 \%$ saline. Hormone stocks were then diluted $\sim 300000$-fold in the aquarium water to give final concentrations of 5 or $50 \mathrm{nM}$. CORT was dissolved in $100 \%$ ethanol and this stock was then diluted in the aquarium water to give a final concentration of 100 or $500 \mathrm{nM}$ (the final concentration of ethanol was 0.0001\%).

Tadpoles were staged based on the system of Nieuwkoop \& Faber (1956). Tadpoles were killed in 0.1\% benzocaine before tissue collection. Animal rearing and dissection procedures were done in accordance with the rules and regulations of the University Committee on the Use and Care of Animals at the University of Michigan.

\section{Hormone extraction and RIA}

Tadpoles were snap frozen and stored at $-80^{\circ} \mathrm{C}$ before hormone extraction. Thyroid hormones were extracted from whole tadpoles following methods described by Denver $(1993,1998 a)$. CORT was extracted from whole tadpoles following the method of Hayes \& Wu (1995) with modifications described by Denver (1998a). Briefly, tadpoles were homogenized in 3-4 volumes of methanol containing $1 \mathrm{mM}$ propylthiouracil for thyroid hormone extraction. For CORT extraction, tadpoles were homogenized in 3-4 volumes of ethyl acetate. For estimation of recoveries, 1000 c.p.m. $\left[{ }^{125} \mathrm{I}\right] \mathrm{T}_{3}$ or 3000 c.p.m. $\left[{ }^{3} \mathrm{H}\right] \mathrm{CORT}$ were added to each extract. Recoveries ranged from 35 to $60 \%$ for $\left[{ }^{125} \mathrm{I}\right] \mathrm{T}_{3}$ and 30 to $45 \%$ for $\left[{ }^{3} \mathrm{H}\right] \mathrm{CORT}$. The validation of these methods for the extraction and recovery of hormones from tadpole tissues is described by Denver (1998a).

The hormones $\mathrm{T}_{3}, \mathrm{~T}_{4}$ and CORT were measured by RIA in extracts of whole $X$. laevis tadpoles. The $T_{3}$ and $T_{4}$ RIAs were as described (Mackenzie et al. 1978, Denver \& Licht 1988, Denver 1998a) and the RIA for CORT was 
described by Licht et al. (1983). Primary antisera for $\mathrm{T}_{3}$ and CORT were purchased from Endocrine Sciences (San Diego, CA, USA). Primary antiserum for $\mathrm{T}_{4}$ was obtained from Dr Viggo Kruse (Denmark). All samples were analyzed in single assays for each hormone.

\section{RNA extraction and Northern blot analysis}

Total RNA was extracted from pooled tadpole tissues (eight to ten brains (diencephalon only), five or six intestines or one to three tails) using Trizol reagent (Invitrogen). For Northern blot analysis total RNA $(10 \mu \mathrm{g})$ was separated by electrophoresis in a $1 \%$ formaldehydeagarose gel, hydrolyzed in $0.05 \mathrm{M} \mathrm{NaOH}, 0.01 \mathrm{M} \mathrm{NaCl}$, and transferred to nylon membrane using $20 \times$ SSC as the transfer buffer. Northern blots were stained with methylene blue to verify the integrity of the RNA and to assess RNA loading. Blots were prehybridized in Hybrisol I (Chemicon, Temecula, CA, USA) for $2-4 \mathrm{~h}$ and hybridized for $16 \mathrm{~h}$ at $42{ }^{\circ} \mathrm{C}$ with ${ }^{32} \mathrm{P}$-labeled probes prepared from cDNAs provided by Yun-Bo Shi (X. laevis; National Institues of Health, USA) TR $\beta$ and ribosomal protein L8; $\mathrm{rpL} 8$ ) and Olivier Destree (X. laevis GR; Utrecht, The Netherlands). cDNAs were labeled with $\left[{ }^{32} \mathrm{P}\right] \mathrm{dCTP}$ by random priming (Roche). Blots were washed with $2 \times$ SSC, $0.5 \%$ SDS at room temperature for $10 \mathrm{~min}$, then $0 \cdot 25 \times \mathrm{SSC}, 0 \cdot 1 \% \mathrm{SDS}$ at $65^{\circ} \mathrm{C}$ for $1 \mathrm{~h}$ before exposure to $\mathrm{X}$-ray film for 1-14 days. Blots were stripped by boiling in $1 \times$ TE $(10 \mathrm{mM}$ Tris, $1 \mathrm{mM}$ EDTA;pH 8.0), $1 \%$ SDS for 5 min and hybridized with a probe for the rpL8 gene (Shi \& Liang 1994) to control for RNA loading.

\section{Data analysis}

Tadpole wet weight (body weight; BW) was measured using a digital balance (accurate to $0.01 \mathrm{~g}$ ). Whole-body hormone contents are expressed as ng hormone/g BW. Previous studies showed that correction of hormone content using either DNA content or wet BW produced identical results (Denver 1993). Following autoradiography, Northern blot data were analyzed using a flatbed scanner and band densities were determined using Scion Image software (version 4.05; Scion Corporation Frederick, MD, USA). Each mRNA data point shown on the graphs represents three or four determinations in which tissues were isolated from tadpoles from different spawns, RNA isolated, and Northern blots prepared. After subtracting background on each Northern blot the densitometric values for GR or TR $\beta$ were normalized to the rpL8 band. Northern blot data were $\log _{10}$-transformed to achieve homogeneity of variance before analysis by oneway ANOVA. Expression data are presented in the graphs as the mean percentage of maximum mRNA level (for developmental expression analyses) or the mean percentage of zero time (for the hormone treatment time course analyses). Hormone data were $\log _{10}$-transformed and
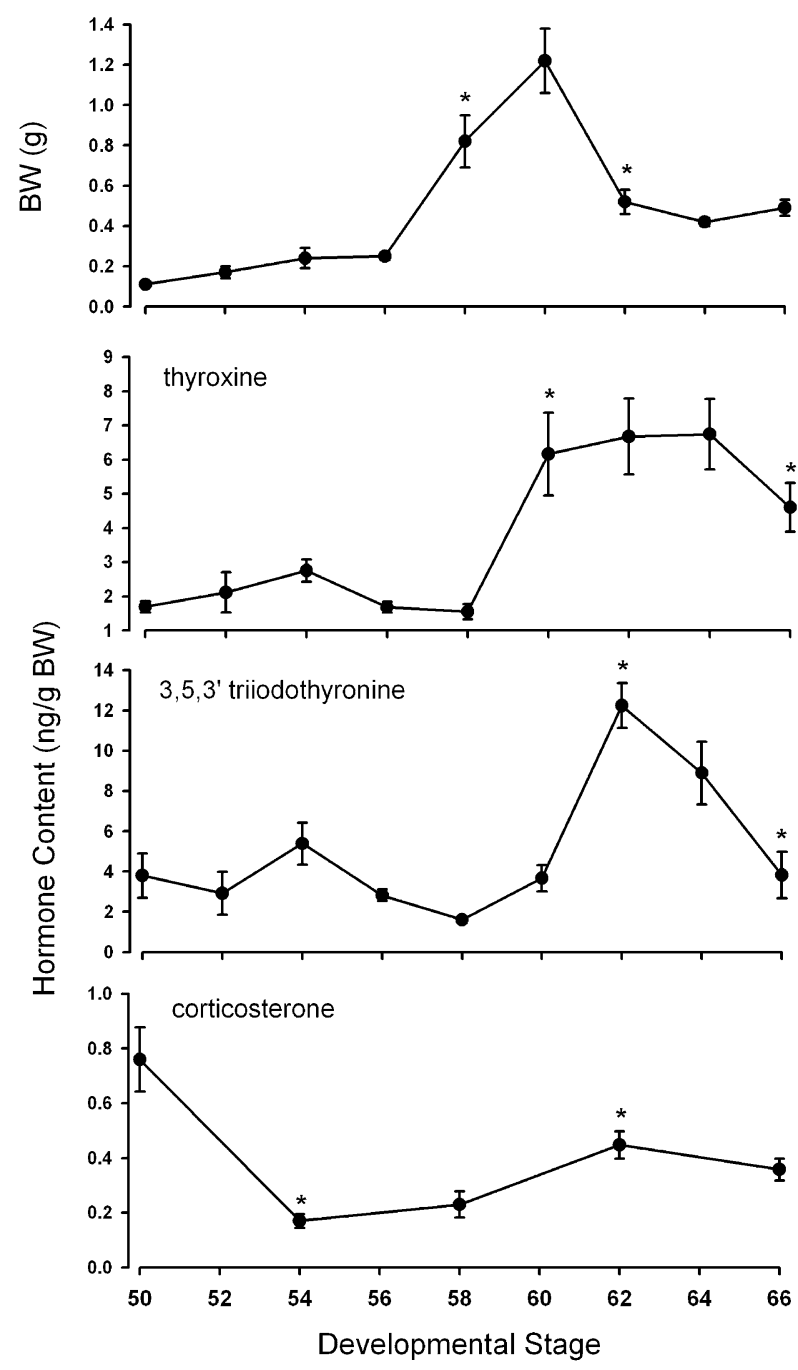

Figure 1 Developmental changes in BW, whole-body $\mathrm{T}_{3}, \mathrm{~T}_{4}$ and CORT content in $X$. laevis during metamorphosis. Thyroid hormone contents were determined by RIA following organic extraction as described in Materials and Methods. Data in the CORT Figure are modified from Glennemeier \& Denver (2002). Each point represents the mean \pm S.E.M. ( $n=6-8 /$ stage). The asterisks designate significant differences from the preceding developmental stage $(P<0 \cdot 05$; Scheffe's test $)$.

analyzed by one-way ANOVA followed by a post-hoc test (Scheffe's multiple contrast test; $P<0 \cdot 05$ ).

\section{Results}

\section{Developmental profiles of whole-body $T_{3}, T_{4}$ and CORT}

We measured whole-body content of $\mathrm{T}_{3}$ and $\mathrm{T}_{4}$ in $X$. laevis tadpoles from premetamorphosis through to the end of metamorphosis (Fig. 1). This analysis showed the expected activation of the thyroid system characteristic of 
anuran metamorphosis. Whole-body $\mathrm{T}_{3}$ and $\mathrm{T}_{4}$ content remained low and relatively constant during premetamorphosis and early prometamorphosis. Whole-body $\mathrm{T}_{4}$ showed a strong increase (4-fold) from NF stage 58 to stage 60 and remained elevated throughout metamorphosis $\left(P<0 \cdot 001\right.$; ANOVA). Mean whole-body $\mathrm{T}_{4}$ content declined after metamorphic climax, and although the mean was approximately twice that of premetamorphic values, this difference was not statistically significant. Peak whole-body $\mathrm{T}_{4}$ content $(\sim 6.5 \mathrm{ng} / \mathrm{g} \mathrm{BW})$ equals roughly $7 \mathrm{nM}$, which compares with a peak plasma concentration of $\sim 10 \mathrm{nM}$ as reported by Leloup \& Buscaglia (1977) for $X$. laevis. For comparison, peak whole-body $\mathrm{T}_{4}$ content was 7 and $10 \mathrm{nM}$ in larvae of Bufo japonicus (Niinuma et al. 1991) and B. marinus (Weber et al. 1994) respectively.

By contrast, the increase in whole-body $\mathrm{T}_{3}$ content (3.3-fold) lagged behind changes in $\mathrm{T}_{4}$; whole-body $\mathrm{T}_{3}$ did not show a statistically significant elevation until stage 62. Whole-body $\mathrm{T}_{3}$ content remained elevated at stage 64 and declined after metamorphosis to levels seen in preand prometamorphic tadpoles $(P<0 \cdot 001 ;$ ANOVA). Peak whole-body $\mathrm{T}_{3}$ content $(\sim 12 \mathrm{ng} / \mathrm{g} \mathrm{BW})$ equals roughly $18 \mathrm{nM}$, which compares with a peak (NF stage 62) plasma $\mathrm{T}_{3}$ concentration of $8 \mathrm{nM}$ as reported by Leloup \& Buscaglia (1977) for X. laevis. For comparison, peak whole-body $\mathrm{T}_{3}$ content was 6 and $8 \mathrm{nM}$ in larvae of $B$. japonicus (Niinuma et al. 1991) and B. marinus (Weber et al. 1994) respectively.

Data for developmental changes in whole-body CORT content are derived from Glennemeier \& Denver (2002). By contrast to whole-body thyroid hormone content, whole-body CORT content was highest during premetamorphosis, declined significantly at the onset of prometamorphosis, but then rose slightly during metamorphic climax (stage 62; $P<0 \cdot 0001$; ANOVA).

Developmental expression of TR $\beta$ and GR mRNAs in brain, intestine and tail during metamorphosis

We compared the developmental expression of TR $\beta$ and GR mRNAs in tadpole brain, intestine and tail by Northern blotting (Figs 2 and 3). TR $\beta$ mRNA levels were low and unchanging during premetamorphosis and early prometamorphosis but increased significantly in all tissues during late prometamorphosis $(P<0 \cdot 001$; ANOVA). The earliest elevation in brain TR $\beta$ mRNA level was detected at stage 58 . By contrast, TR $\beta$ mRNA levels increased later in the intestine and tail (stage 60). Maximal expression occurred in the brain at stage 60 , in the intestine at stage 62 and in the tail at stage 64 . The TR $\beta$ mRNA levels in the brain of the juvenile frog remained at a late prometamorphic level (compared with stage 58) but returned to premetamorphic levels in the intestine.

Three GR transcripts of 8,5 and $3 \mathrm{~kb}$ were detected by Northern blot in the brain, intestine and tail (blot shown in Fig. 3 for brain only). The $8 \mathrm{~kb}$ transcript is not present in embryos and is expressed only after hatching where it becomes the predominant transcript (data not shown for embryonic expression; see also Gao et al. 1994). Similarly, we found that several X. laevis cell lines (XTC-2, XL-58, A6, XL-177) expressed only the two smaller GR transcripts (data not shown; see also Spindler \& Verrey (1999) for A6 cells).

Expression of GR mRNA in brain showed significant changes during metamorphosis, approximately doubling between premetamorphic and early prometamorphic stages (compare stages 49 and 52; $P<0 \cdot 0001$; ANOVA). Brain GR mRNA was then expressed at a constant level until after metamorphosis when it increased approximately $40 \%$ above levels seen at metamorphic climax. In the intestine, GR mRNA was expressed at a constant level during metamorphosis. There was a trend towards an increase $(\sim 20 \%)$ in the mean GR mRNA level at stage 60 , which corresponds to the stage when TR $\beta$ mRNA is strongly upregulated and the intestine begins to remodel (reviewed by Shi 2000). The level of GR mRNA in the juvenile intestine then declined approximately $20 \%$ relative to metamorphic levels. The strongest developmental regulation of GR mRNA was seen in the tail where levels increased throughout prometamorphosis and peaked at metamorphic climax ( 3 -fold above early prometamorphic levels; $P<0 \cdot 05)$ when the tail is actively resorbing.

\section{Effects of exogenous $T_{3}$ on nuclear hormone receptor $m R N A$} levels

Addition of $\mathrm{T}_{3}(50 \mathrm{nM})$ to the rearing water caused statistically significant increases in TR $\beta$ mRNA levels in all tissues $(P<0.0001$ for all; ANOVA; Fig. 4). The kinetics of upregulation was similar among the different tissues; statistically significant increases in TR $\beta$ transcripts were detected at $16 \mathrm{~h}$ in all tissues. It is likely that the upregulation occurred earlier than $16 \mathrm{~h}$, since we and others have detected TR $\beta$ upregulation by $8-12 \mathrm{~h}$ (L P Krain \& R J Denver, unpublished observations; Yaoita \& Brown 1990, Kanamori \& Brown 1992, Eliceiri \& Brown 1994, Furlow \& Brown 1999).

While the kinetics of TR $\beta$ upregulation was similar in the three tissues analyzed, the dose sensitivity differed. Data for the $50 \mathrm{nM}$ dose of $\mathrm{T}_{3}$ are shown in Fig. 4. Treatment with $5 \mathrm{nM} \mathrm{T} \mathrm{T}_{3}$ produced a similar increase in TR $\beta$ mRNA in brain and intestine, but did not influence $\operatorname{TR} \beta$ gene expression in the tail (data not shown). Others have documented the relative insensitivity of gene expression in the tadpole tail to exogenous $T_{3}$, which is the last tissue to transform (reviewed by Shi 2000).

By contrast to TR $\beta, T_{3}$ treatment downregulated GR mRNA in the brain $(P<0 \cdot 001$; ANOVA; Fig. 5). A significant reduction in brain GR mRNA was detected by $24 \mathrm{~h}$ after exposure to $\mathrm{T}_{3}$ (both 5 and $50 \mathrm{nM} \mathrm{T}_{3}$ - only the $50 \mathrm{nM}$ dose is shown in Fig. 5). The effect of exogenous 
(A)

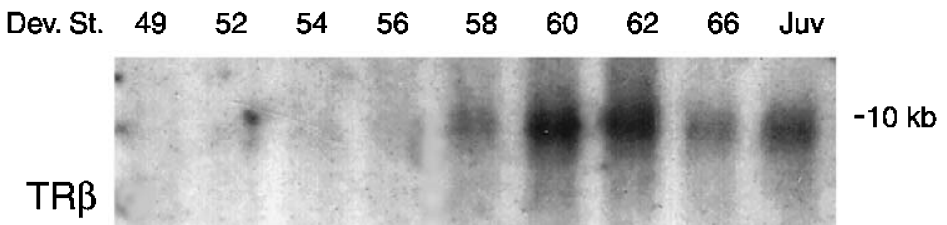

$-3.8 \mathrm{~kb}$

rpL8

(B)

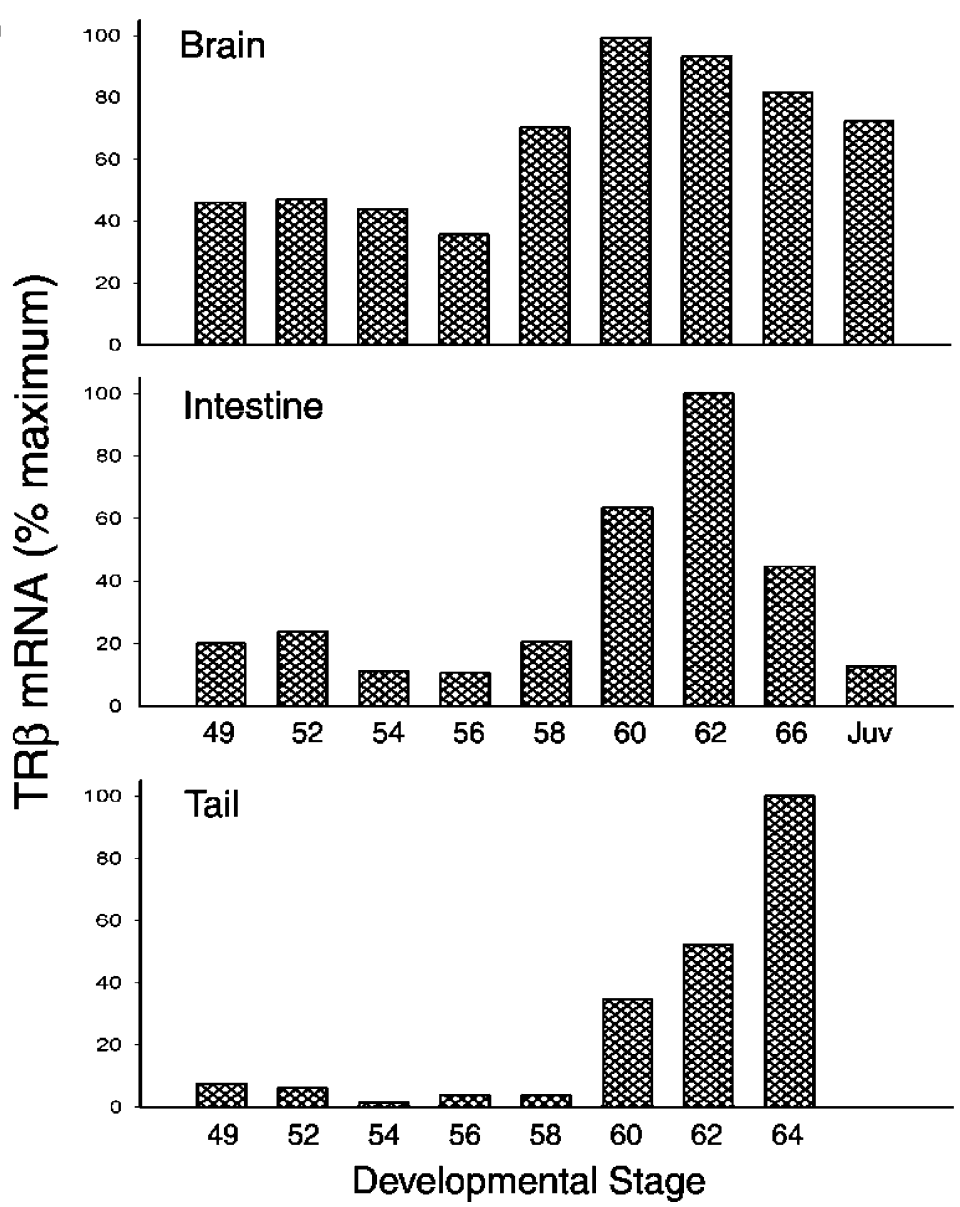

Figure 2 Developmental expression of TR $\beta$ mRNA in brain, intestine and tail during metamorphosis. TR $\beta$ expression was analyzed by Northern blotting as described in Materials and Methods. A representative Northern blot in brain is shown at the top (A). The graphs (B) show the quantitation of mRNA levels based on densitometric analysis of scanned autoradiograms. TR $\beta$ mRNA was normalized to the rpL8 band. Data are expressed as percentage of maximum. Each bar represents the mean of three independent experiments.

$\mathrm{T}_{3}(5$ or $50 \mathrm{nM})$ on GR mRNA levels in the intestine was biphasic, with a transient upregulation followed by a downregulation. The increases in intestinal GR mRNA levels $(8-24 \mathrm{~h})$ were not statistically significant but the decreases at 48 and $72 \mathrm{~h}$ were $(P<0 \cdot 05)$. In the tail, $50 \mathrm{nM} \mathrm{T}_{3}$ upregulated GR mRNA, with a maximum level of expression at $72 \mathrm{~h}(\sim 3$-fold above the 0 time value; $P<0 \cdot 01)$. Note that this magnitude of change in 


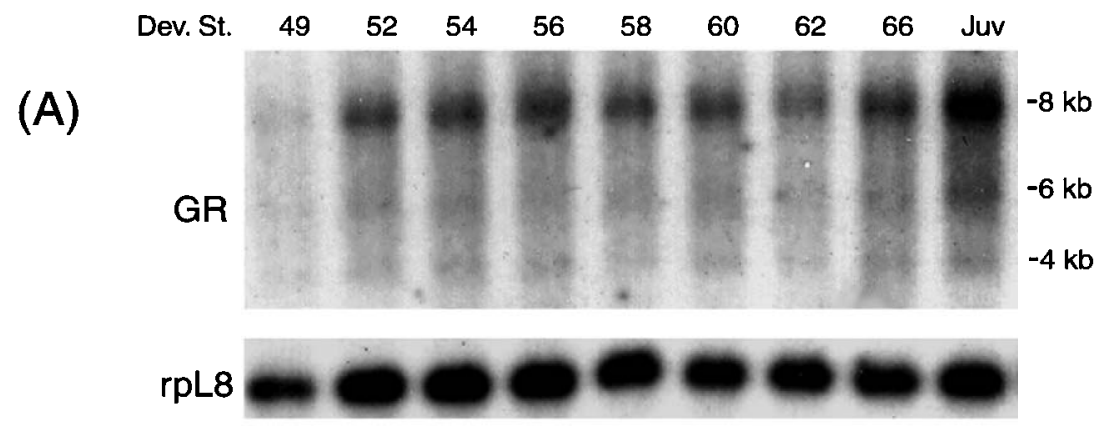

(B)

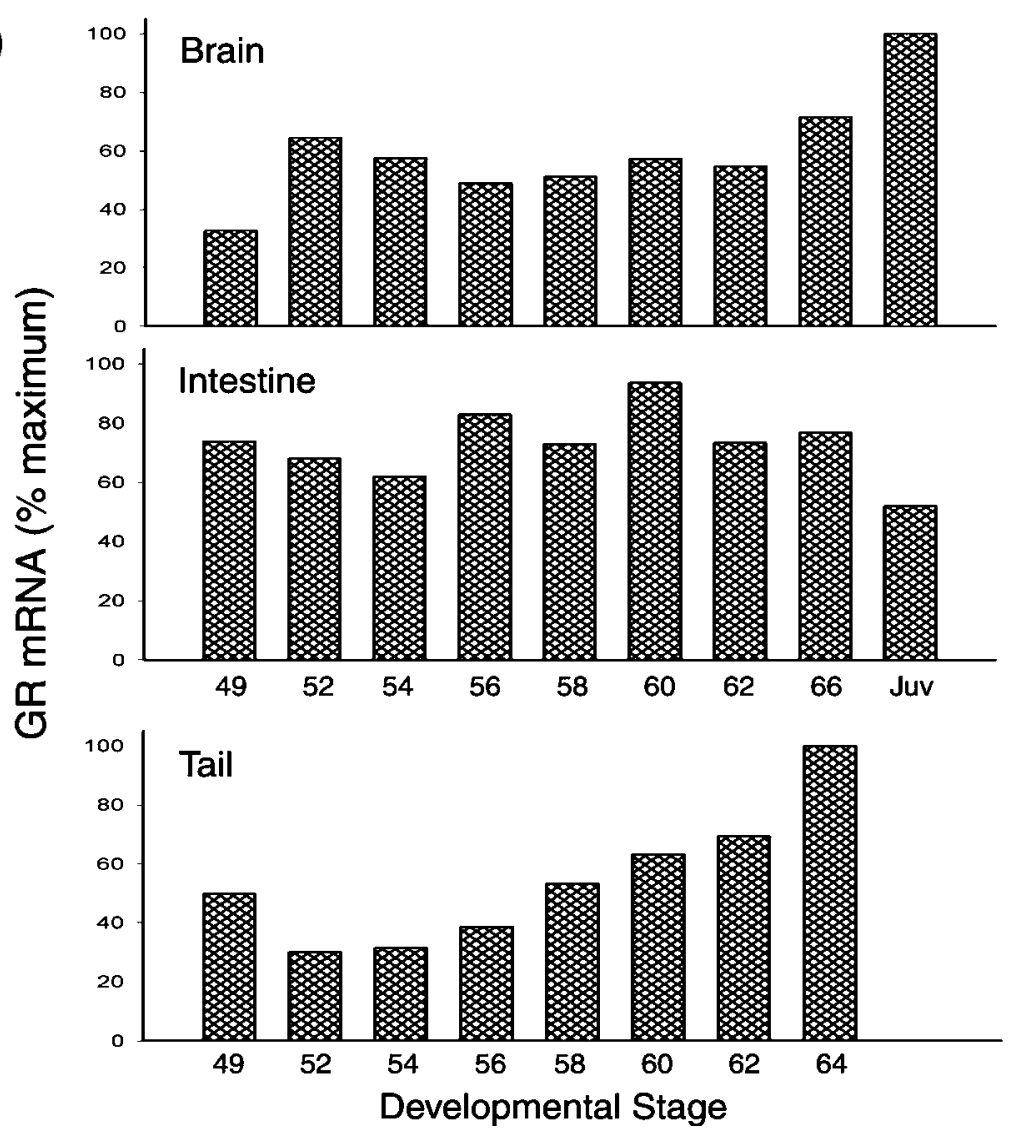

Figure 3 Developmental expression of GR mRNA in brain, intestine and tail during metamorphosis. GR expression was analyzed by Northern blotting as described in Materials and Methods. A representative Northern blot in brain is shown at the top (A). The graphs (B) show the quantitation of mRNA levels based on densitometric analysis of scanned autoradiograms. GR mRNA was normalized to the rpL8 band. Data are expressed as percentage of maximum. Each bar represents the mean of three independent experiments.

gene expression is comparable with that seen in the tail during spontaneous metamorphosis (Fig. 3).

Changes in whole-body $T_{3}$ content following exposure to exogenous $T_{3}$

It is generally assumed that the tissue content/plasma concentration of thyroid hormones achieved by addition of hormone to the tadpole-rearing water equals the nominal concentration in the aquarium water i.e. tadpoles equilibrate with their environment. The choice of a $5 \mathrm{nM}$ dose of $\mathrm{T}_{3}$ in many studies in $X$. laevis is based upon this assumption (Shi \& Brown 1993), and the report by Leloup \& Buscaglia (1977) that peak plasma $\mathrm{T}_{3}$ concentration during metamorphosis in this species reaches $\sim 8 \mathrm{nM}$. To test this assumption we analyzed whole-body $\mathrm{T}_{3}$ content 
T3 (h): $\quad \begin{array}{lllllll}0 & 4 & 8 & 16 & 24 & 48 & 72\end{array}$

(A)

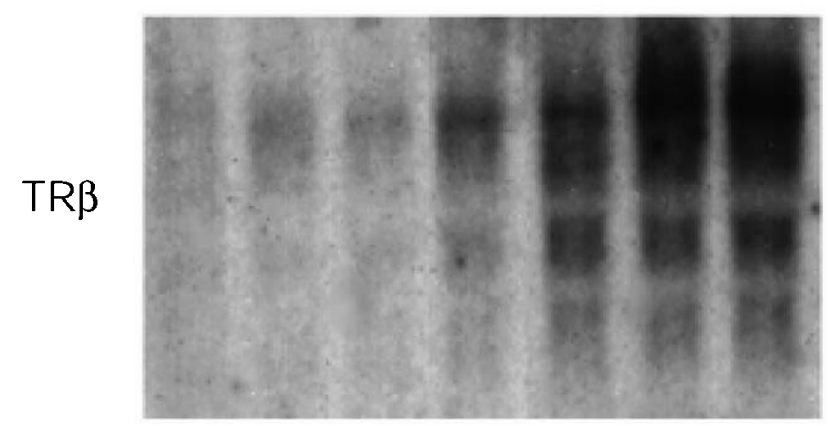

rpL8

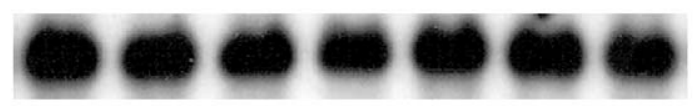

(B)

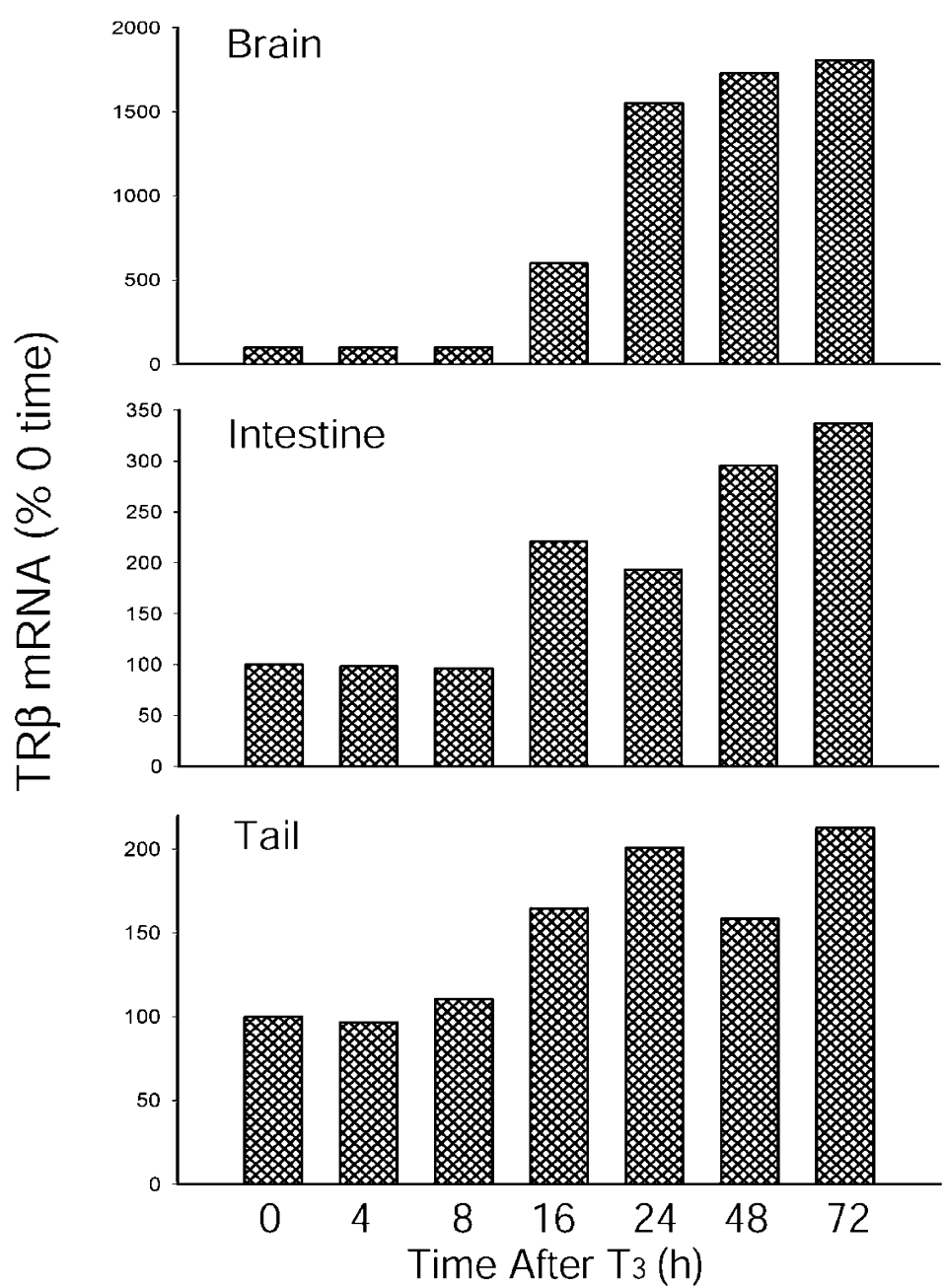

Figure 4 Effects of in vivo $T_{3}$ treatment on TR $\beta$ mRNA in brain, tail and intestine. Tadpoles were exposed to $T_{3}$ ( $50 \mathrm{nM}$ in the aquarium water) for various times before harvest for tissue isolation, RNA extraction and Northern blot analysis. Water was changed and the $T_{3}$ was replenished every $24 \mathrm{~h}$. A representative Northern blot from brain is shown at the top (A). The graphs (B) show the quantitation of mRNA levels based on densitometric analysis of scanned autoradiograms. TR $\beta$ mRNA was normalized to the rpL8 band. Data are expressed as percentage of the zero time value. Each bar represents the mean of four independent experiments. 


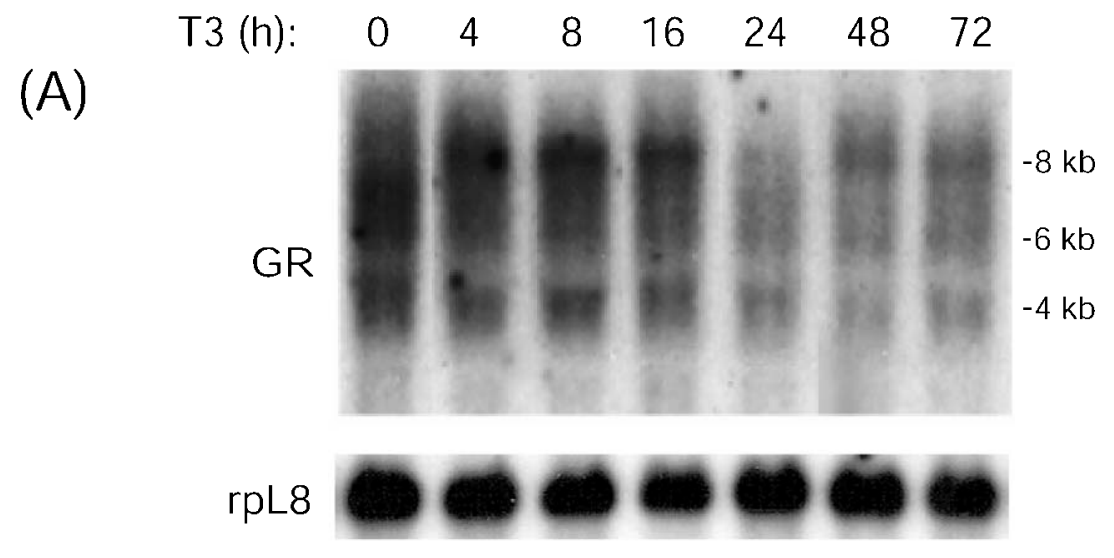

(B)

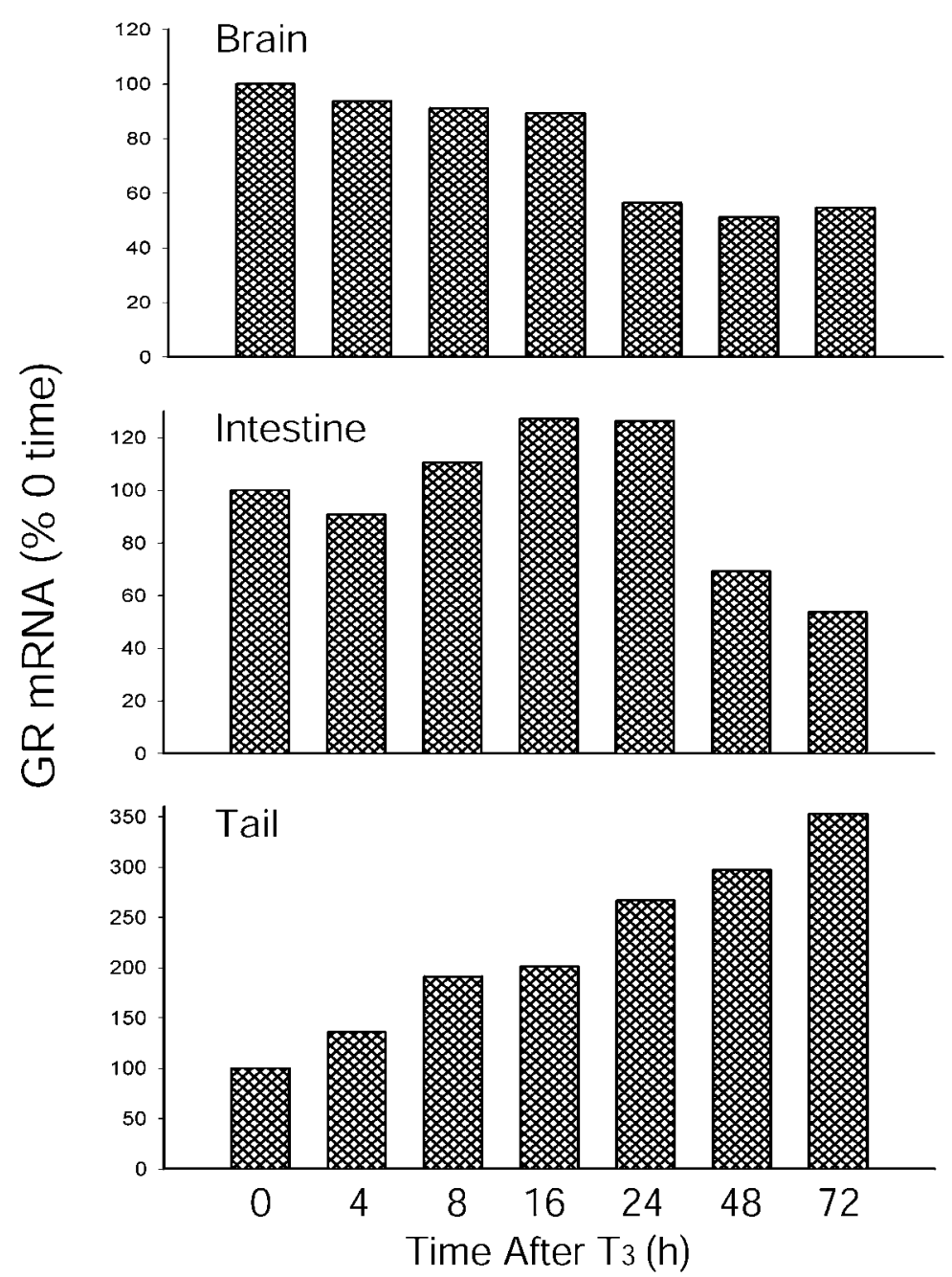

Figure 5 Effects of in vivo $T_{3}$ treatment on GR mRNA in brain, tail and intestine. Tadpoles were exposed to $\mathrm{T}_{3}$ (50 $\mathrm{nM}$ in the aquarium water) for various times before harvest for tissue isolation, RNA extraction and Northern blot analysis. Water was changed and the $T_{3}$ was replenished every $24 \mathrm{~h}$. A representative Northern blot from brain is shown at the top (A). The graphs (B) show the quantitation of mRNA levels based on densitometric analysis of scanned autoradiograms. GR mRNA was normalized to the rpL8 band. Data are expressed as percentage of the zero time value. Each bar represents the mean of four independent experiments. 

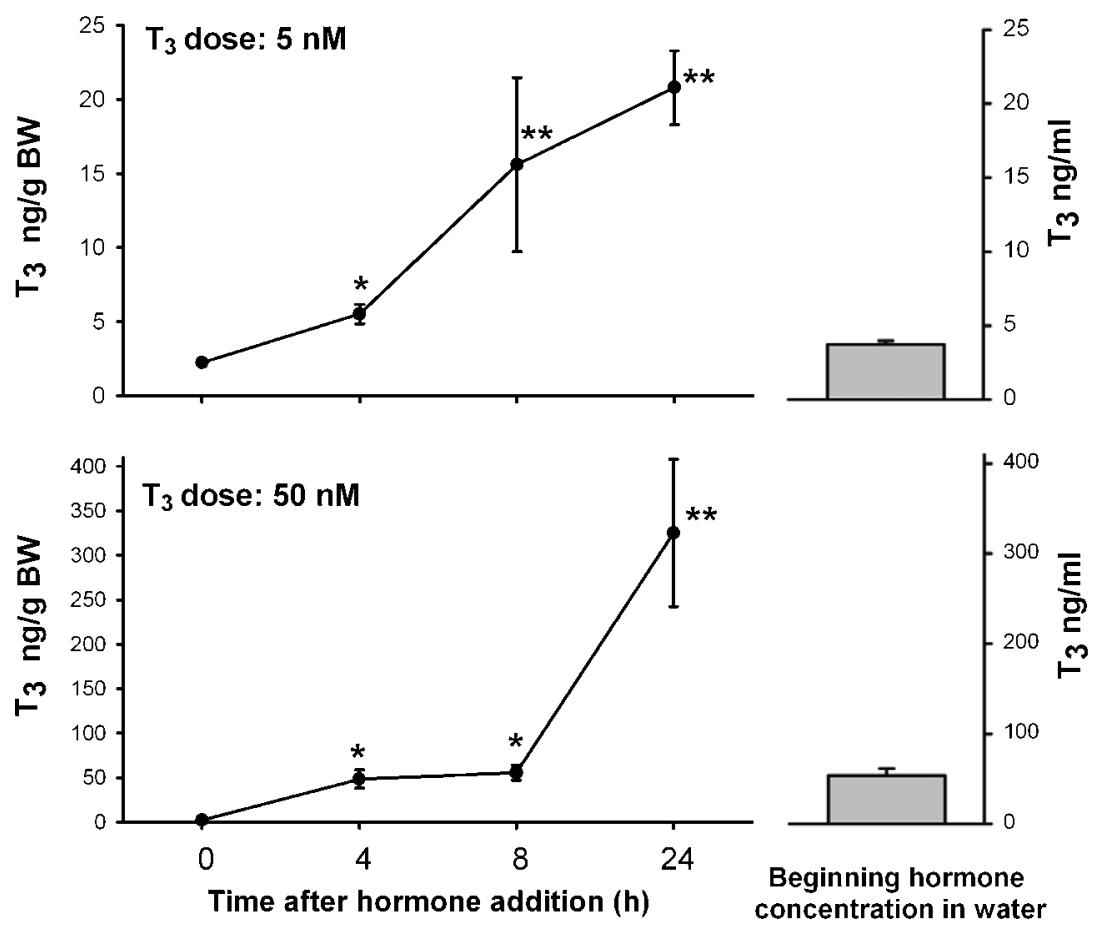

Figure 6 Time-dependent changes in whole-body $T_{3}$ content following exposure of premetamorphic tadpoles to two doses of $T_{3}$ in the aquarium water. $T_{3}$ was added to the aquarium water at time $=0$ and tadpoles were collected at various times and analyzed for whole-body $\mathrm{T}_{3}$ content by RIA following organic extraction as described in Materials and Methods. Each point represents the mean $(n=8 /$ time point) and vertical bars the S.E.M. ${ }^{*}$ Significantly different from zero time $(P<0 \cdot 001) ;{ }^{*}$ significantly different from zero time and from the ambient $\mathrm{T}_{3}$ concentration $(P<0 \cdot 0001)$.

in NF stage 52 tadpoles reared in aquarium water with two different doses of $\mathrm{T}_{3}$ for various times. The nominal hormone concentrations in the aquarium water achieved were $\sim 6 \mathrm{nM}$ (for the intended $5 \mathrm{nM}$ dose) and $\sim 70 \mathrm{nM}$ (for the intended $50 \mathrm{nM}$ dose; Fig. 6). Our analysis showed that tadpole tissue hormone content reached environmental concentrations within $4 \mathrm{~h}$ of immersion for both doses (Fig. 6; compare line graphs with bars which show the concentration of $\mathrm{T}_{3}$ in the water.) However, the $\mathrm{T}_{3}$ tissue content continued to increase and reached a level that was 4-6 times greater than the beginning environmental concentration. The final whole-body $\mathrm{T}_{3}$ concentration achieved was $\sim 24 \mathrm{nM}$ for the low dose and $\sim 480 \mathrm{nM}$ for the high dose. Thus, treatment of tadpoles with $\mathrm{T}_{3}$ by addition to the aquarium water results in pharmacological levels of the hormone in tadpole tissues.

\section{Effects of exogenous CORT on nuclear hormone receptor $m R N A$ levels}

In this experiment CORT was added to the rearing water to a final concentration of $100 \mathrm{nM}$ and tadpoles were killed at different times thereafter up to $72 \mathrm{~h}$. The water was not changed during the experiment (i.e. the CORT was not replenished). No effect of CORT treatment on nuclear receptor mRNA was observed in the brain or tail (data not shown). In the intestine, CORT treatment resulted in a rapid, but transient upregulation of GR and TR $\beta$ mRNAs (Fig. 7).

Changes in whole-body CORT content following exposure to exogenous CORT

Analysis of whole-body CORT content following addition of CORT to a final concentration of $100 \mathrm{nM}$ (nominal concentration achieved $\sim 125 \mathrm{nM}$ ) or $500 \mathrm{nM}$ (nominal concentration achieved $\sim 550 \mathrm{nM}$ ) to the aquarium water showed that while tissue CORT content increased rapidly, tissue content never reached the environmental concentration (Fig. 8). Furthermore, whole-body CORT content declined at 24 and $48 \mathrm{~h}$ following addition to the aquarium water. For the $100 \mathrm{nM}$ dose, whole-body CORT content was significantly elevated at $2 \mathrm{~h}$ after addition of hormone to the aquarium water $(P<0 \cdot 001$; ANOVA), continued to rise up to $8 \mathrm{~h}$, but then declined at 24 and $48 \mathrm{~h}$ (but remained elevated above the 0 time value). For the $500 \mathrm{nM}$ dose, tissue CORT content was significantly elevated at $2 \mathrm{~h}$ after 


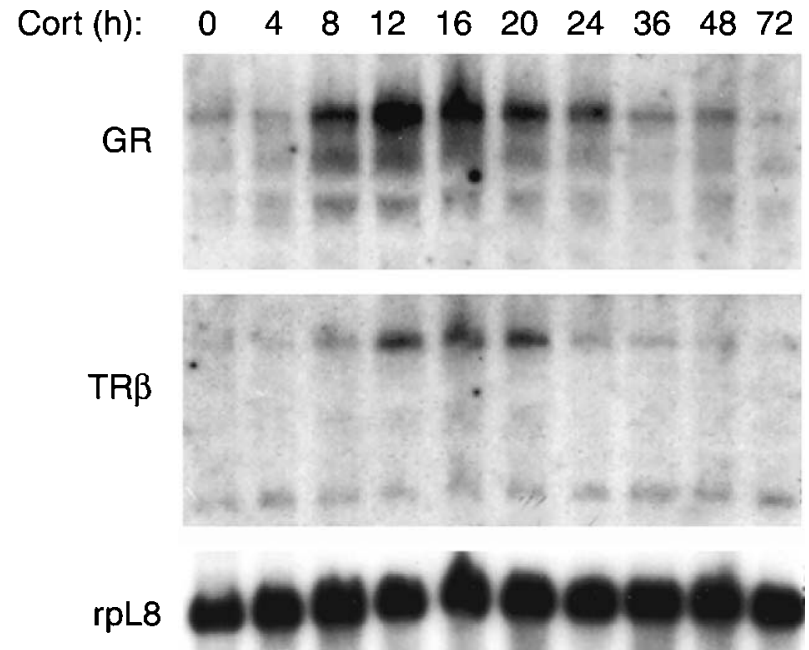

Figure 7 Effects of in vivo CORT treatment on GR and TR $\beta$ mRNA levels in premetamorphic tadpole intestine. CORT was added to the aquarium water to a final concentration of $100 \mathrm{nM}$ at time zero and tadpoles harvested at various times for tissue isolation, RNA extraction and Northern blot analysis. TR $\beta$ and GR mRNAs were analyzed by Northern blotting as described in Materials and Methods.

addition of hormone to the aquarium water $(P<0 \cdot 0001)$, but then gradually declined to $48 \mathrm{~h}$ (but remained elevated above the 0 time value).

\section{Discussion}

Corticosteroids have long been implicated in the positive control of amphibian metamorphosis, but little is known about their mechanism of action. This is the first study to analyze the developmental expression and hormonal regulation of GR mRNA, and to compare GR with TR $\beta$ gene expression in $X$. laevis during metamorphosis. Our results show that the expression of GR mRNA increases in the brain and tail during metamorphosis. The strong upregulation of GR in the tail leading up to metamorphic climax may provide the molecular basis for corticosteroid enhancement of $\mathrm{T}_{3}$-dependent tail regression (reviewed by Kikuyama et al. 1993). This accumulation of GR transcripts in tail may be mediated by rising plasma thyroid hormone concentrations, since we also found that exogenous $\mathrm{T}_{3}$ increased GR mRNA in this tissue. Our data support the findings of others that show that there are tissue-specific differences in the timing of the onset of TR $\beta$ expression and its peak, which may underlie the asynchronous tissue morphogenesis that occurs during spontaneous metamorphosis. Our studies also highlight important methodological issues relating to the administration of hormones in the aquarium water, and assump-
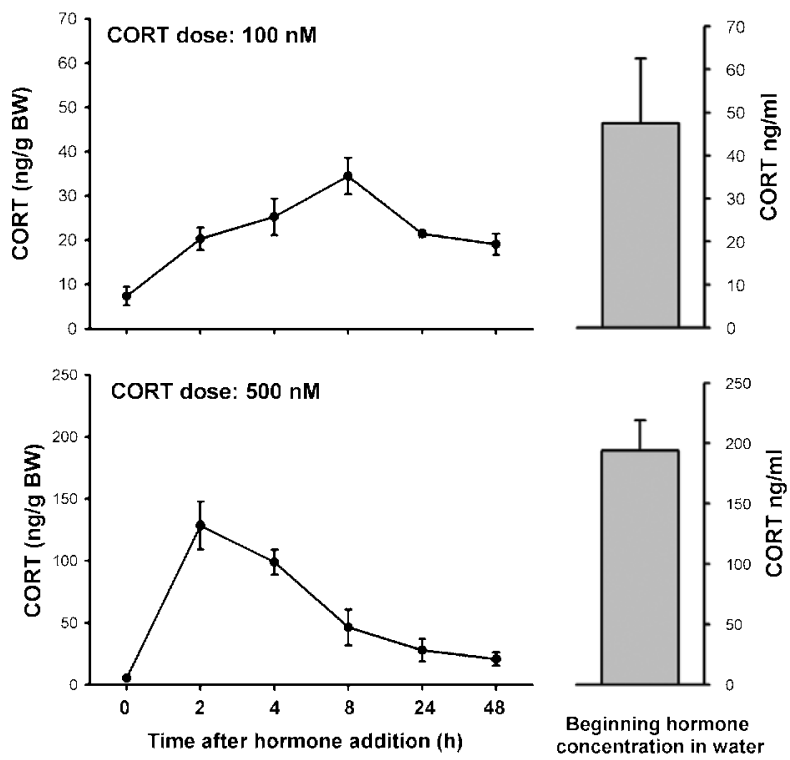

Figure 8 Changes in whole-body CORT content following exposure of premetamorphic tadpoles to two different doses of CORT in the aquarium water. The CORT was added to the aquarium water at time $=0$ and tadpoles were collected at various times and analyzed for whole-body CORT content by RIA following organic extraction as described in Materials and Methods. Each point represents the mean ( $n=8 /$ time point) and vertical bars the S.E.M.

tions about tissue hormone content achieved by such administrations.

\section{Developmental patterns of hormone production and nuclear receptor expression}

Thyroid hormones and TR $\beta$ Our analyses of wholebody $\mathrm{T}_{3}$ and $\mathrm{T}_{4}$ showed that both hormones exhibited the expected increases during prometamorphosis and metamorphic climax in $X$. laevis as has been described for whole-body thyroid hormone content in other species (Niinuma et al. 1991, Weber et al. 1994, Denver 1998a) and for plasma thyroid hormone concentrations in X. laevis (Leloup \& Buscaglia 1977, Tata et al. 1993) and other anurans (Regard et al. 1978, Mondou \& Kaltenbach 1979, Weil 1986). We found that peak tissue hormone contents in $X$. laevis were comparable with those reported for other anurans (Niinuma et al. 1991, Weber et al. 1994, Denver 1998a). The whole-body $\mathrm{T}_{3} / \mathrm{T}_{4}$ ratio was highest at stage 62 , which is consistent with the upregulation of deiodinase type II (D2) at this stage of development in tadpoles (shown for D2 activity and mRNA in various tissues of tadpoles of Rana catesbeiana (Becker et al. 1997), also D2 mRNA in X. laevis pituitary (R G Manzon \& R J Denver, unpublished observations)).

It is worth noting that Leloup \& Buscaglia (1977) did not report a significant rise in plasma $T_{4}$ or $T_{3}$ until NF 
stages 59-60. Similarly, Tata (1993) was also unable to detect an increase in plasma $T_{3}$ until these late prometamorphic stages. Findings in $X$. laevis are also consistent with measures of plasma $T_{4}$ and $T_{3}$ in the bullfrog, $R$. catesbeiana, where significant increases in plasma hormone concentration were not observed until late prometamorphosis/early climax (Regard et al. 1978). Thus, the published plasma $T_{3}$ and $T_{4}$ concentrations in tadpoles during metamorphosis are consistent with our measures of whole-body hormone content, which showed significant increases only during late prometamorphosis. However, failure to detect significant elevations in thyroid hormones in tadpole plasma or tissues at earlier developmental stages likely reflects limitations in the sensitivity of the methods used. This conclusion is supported by findings that treatment with goitrogens can block metamorphosis when administered during premetamorphosis or early prometamorphosis (e.g. see Denver et al. 1997).

It is now well established that TR $\beta$ mRNA increases during tadpole metamorphosis (Yaoita \& Brown 1990, reviewed by Shi 2000). Many of the earlier studies relied on measures of gene expression in whole tadpoles, or gross regions such as the head or 'middle'. In the current study we systematically compared the developmental and hormone-regulated expression of TR $\beta$ mRNA in brain, intestine and tail. We found that the developmental expression of TR $\beta$ mRNA roughly paralleled changes in whole-body thyroid hormone content. However, the timing of the onset of TR $\beta$ expression, and the stage of maximum expression, differed among the tissues analyzed. TR $\beta$ mRNA was highest for each tissue at the time of its major metamorphic change (Shi 2000). Wong \& Shi (1995) reported nearly identical patterns of TR $\beta$ gene expression in the intestine and tail as we do. Others have reported highest TR $\beta$ mRNA (and protein) expression at stage 62 in X. laevis tadpole 'head' (Kawahara et al. 1991, Eliceiri \& Brown 1994).

The expression of TR $\beta$ during metamorphosis depends on thyroid hormone (reviewed by Shi 2000). In all X. laevis tadpole tissues studied to date TR $\beta$ mRNA is upregulated by its ligand (i.e. it is autoinduced; see Fig. 4; Shi 2000). Sensitivity to the hormone differs among tissues, with the tail being the least sensitive. The difference in the timing of the onset and maximal TR $\beta$ mRNA levels among tissues likely reflects these differences in sensitivity to hormonal stimulation. In the brain, $\operatorname{TR} \beta$ mRNA increased slightly before the rise in whole-body $\mathrm{T}_{4}$ (stage 58 vs 60) and four developmental stages before the rise in whole-body $\mathrm{T}_{3}$ (at stage 62). As for the inhibitory effects of goitrogens on premetamorphic and early prometamorphic tadpoles mentioned above, the earlier expression of TR $\beta$ (before increases in plasma or tissue thyroid hormone can be detected) further supports the conclusion that the sensitivity of the methods used to assay for thyroid hormones is limiting. Morphological and gene expression data support the view that the brain is more sensitive to $\mathrm{T}_{3}$ than most other tadpole tissues (not including the hind limb, which may show the earliest responses to $\mathrm{T}_{3}$; see Kawahara et al. 1991, Denver 1998b). $\operatorname{TR} \beta$ mRNA levels in the intestine and tail increased at the time when $\mathrm{T}_{4}$ content was first elevated (stage 60) and continued to increase through metamorphic climax. Maximal TR $\beta$ mRNA level in the intestine (stage 62) was coincident with the peak in whole-body $\mathrm{T}_{3}$ content, while maximal TR $\beta$ mRNA level in the tail (stage 64) occurred when $T_{3}$ was beginning to decline.

CORT and GR In X. laevis, CORT was found to be the major corticosteroid in plasma, with lesser amounts of aldosterone (Jolivet-Jaudet \& Leloup-Hatey 1984, Kikuyama et al. 1993). As we (Glennemeier \& Denver 2002) and Kloas et al. (1997) reported previously, wholebody CORT is highest during premetamorphosis and drops dramatically at the onset of prometamorphosis. Unlike Kloas and colleagues, we observed a small but significant rise in whole-body CORT at metamorphic climax (stage 62). This rise in whole-body CORT at metamorphic climax is consistent with increased plasma CORT concentrations at this stage as reported by LeloupHatey and colleagues for $X$. laevis (Jolivet-Jaudet \& Leloup-Hatey 1984, Leloup-Hatey et al. 1988) and in other amphibian species (Kikuyama et al. 1993). LeloupHatey et al. (1988) also analyzed changes in CORT content in individual tissues (front and rear legs, tail, intestine, skin and liver) and found increased CORT content in some but not all tissues as metamorphosis proceeded.

Unlike TR $\beta$ mRNA, which is ubiquitously upregulated in tadpole tissues during metamorphosis, the developmental expression of GR mRNA differed among tissues. We found that tail GR mRNA increased throughout prometamorphosis and reached a maximum at metamorphic climax (stage 64). Leloup-Hatey et al. (1988) reported a large increase in CORT content in the $X$. laevis tail at the end of metamorphic climax (stage 64), which would be consistent with an increased number of CORTbinding sites (reflected in increased GR mRNA) in the tail at this developmental stage. High-affinity corticosteroid-binding sites have been demonstrated in cytosolic fractions of liver, intestine and tailfin of tadpoles of X. laevis (reviewed by Kikuyama et al. 1993).

By contrast to the ubiquitous upregulation of $\operatorname{TR} \beta$ by its ligand in $X$. laevis tissues, the regulation of GR expression by CORT appears to be tissue-specific. Both up- and downregulation of corticosteroid receptor gene expression by corticosteroids have been reported in mammalian cells (Schmidt \& Meyer 1994). In the tadpole intestine we found that GR mRNA was upregulated by CORT, but was unaffected in the brain or tail. Whether this regulation in the intestine has physiological significance is uncertain, since the intestinal GR mRNA level did not change significantly during spontaneous 
metamorphosis. The level of brain GR mRNA was low during premetamorphosis but increased significantly during prometamorphosis and remained at a constant level throughout metamorphosis. This increase in brain GR mRNA in early prometamorphosis is correlated with a dramatic drop in whole-body CORT content at this time. Although we did not find that CORT altered GR mRNA in the brain in the current study, other findings of ours suggest that brain GR mRNA may be negatively regulated by corticosteroids (L P Krain \& R J Denver, unpublished observations). Negative regulation of GR (and MR) by corticosteroids has been reported in the $X$. laevis kidney cell line A6 (Hagley \& Watlington 1996, Spindler \& Verrey 1999). Thus, if brain GR is negatively regulated by CORT then the increase in brain GR mRNA at the onset of prometamorphosis could depend on the decline in corticosteroid biosynthesis.

\section{Crossregulation of nuclear hormone receptors}

$T_{3}$ regulation of GR There are numerous examples of crossregulation of nuclear hormone receptor expression in animals (see Tata 1994). For example, in X. laevis liver cells estrogen receptor expression is regulated by thyroid hormone and glucocorticoids (Ulisse \& Tata 1994). In the current study we found that $T_{3}$ upregulated GR expression in the tail, and this regulation may be consistent with a physiological regulatory relationship, given the developmental pattern of thyroid hormone production and GR mRNA in the tail. Exogenous and endogenous corticosteroids are known to enhance thyroid hormoneinduced and spontaneous metamorphosis (Kikuyama et al. 1993, Hayes 1997). The increase in tail GR mRNA may be driven by increasing plasma titers of $T_{3}$, resulting in increased tissue sensitivity to corticosteroids at metamorphic climax.

By contrast, we found that $\mathrm{T}_{3}$ downregulated GR expression in the brain. Presently, we do not know if this negative regulation of GR by $T_{3}$ in the brain is physiologically relevant, since we did not observe a decline in brain GR mRNA when tissue thyroid hormone content was highest.

CORT regulation of TR $\beta$ Positive regulation of TR expression by GR is implied by the finding that corticosteroids enhance nuclear $\mathrm{T}_{3}$ binding capacity in tadpole tail (Niki et al. 1981, Suzuki \& Kikuyama 1983a). This effect of corticosteroids has been proposed as one mechanism whereby corticosteroids synergize with thyroid hormone to promote morphogenesis (Kikuyama et al. 1993). We found that CORT treatment upregulated TR $\beta$ expression in the intestine but not in the brain or tail of premetamorphic tadpoles. We should note, however, that in tail explant cultures we found that CORT could induce a small but significant increase in TR $\beta$ mRNA
(E D Hoopfer and R J Denver, unpublished observations). Thus, it is possible that CORT can upregulate TR $\beta$ expression in the tail in vivo as it did in the intestine, but our limit of detection was exceeded in the current study.

\section{Methodological issues}

Our findings have highlighted several methodological issues that should be considered when conducting hormone treatments via addition to aquarium water. Animals concentrate $T_{3}$ from the environment and the tissue concentration achieved is several-fold greater than would be predicted based on a simple equilibration with the environment (e.g. see Shi \& Brown 1993). These results highlight the importance of accounting for the endogenous hormone level achieved when evaluating the physiological significance of gene expression that is induced or repressed by exogenous hormone. Our data support the prediction that to achieve a tissue concentration of $\mathrm{T}_{3}$ within the physiological range in $X$. laevis one must work with concentrations in the aquarium water between 0.1 and $2 \mathrm{nM}$.

A second finding is that the increase in tissue content of CORT by tadpole tissues following a single addition of hormone to the aquarium water is transient and decays relatively rapidly. We hypothesize that this phenomenon may account for the transient upregulation of GR and TR $\beta$ mRNAs in the intestine (Fig. 7). Thus, to maintain constant tissue hormone concentrations one may need to frequently replenish the hormone in the tank (static renewal every $8-10 \mathrm{~h}$ ) or use a flow-through system.

\section{Conclusions}

Corticosteroids are the primary circulating stress hormones in vertebrates, and their production is increased following exposure to environmental stress. These stress hormones are known to synergize with thyroid hormone to promote metamorphosis, and links between the thyroid and stress axes are present at multiple levels (e.g. pituitary regulation, deiodinase expression, etc.; see Denver et al. 2002). Thus, a means for modulating the timing of metamorphosis may be to control the production and actions of corticosteroids, which may alter the sensitivity of tadpole tissues to the actions of $\mathrm{T}_{3}$.

The present study focused on tissue hormone content and nuclear hormone receptor gene expression during spontaneous metamorphosis (i.e. in the absence of stress), but whole-body CORT content (and thyroid hormone content) can increase dramatically in tadpoles in response to environmental stress (Glennemeier \& Denver 2002). Such stress-induced alterations in CORT could affect GR or TR $\beta$ expression, and thus the actions of CORT and $\mathrm{T}_{3}$ on target tissues during metamorphosis. 


\section{Acknowledgements}

We are grateful to Brandon Farley and Eric Hoopfer for providing technical assistance.

\section{Funding}

This research was supported by NSF grants IBN 9724080 and IBN 9974672 to R J D. Partial support for L P K was from a training grant administered by the NSF-sponsored Training Program in Developmental Neurobiology at the University of Michigan. This work was supported in part by a grant from the National Institute of Diabetes and Digestive Kidney Disease of the National Institutes of Health (No. 5P60DK20572) to the Michigan Diabetes Research Training Center. The authors verify that there are no conflicts of interest.

\section{References}

Becker KB, Stephens KC, Davey JC, Schneider MJ \& Galton VA 1997 The type 2 and type 3 iodothyronine deiodinases play important roles in coordinating development in Rana catesbeiana tadpoles. Endocrinology 138 2989-2997.

Carr JA \& Norris DO 1988 Interrenal activity during metamorphosis of the tiger salamander, Ambystoma tigrinum. General and Comparative Endocrinology 71 63-69.

Csikos T, Tay J \& Danielsen M 1995 Expression of the Xenopus laevis mineralocorticoid receptor during metamorphosis. Recent Progress in Hormone Research 50 393-396.

Denver RJ 1993 Acceleration of anuran amphibian metamorphosis by corticotropin-releasing hormone-like peptides. General and Comparative Endocrinology 91 38-51.

Denver RJ 1998a Hormonal correlates of environmentally induced metamorphosis in the Western spadefoot toad, Scaphiopus hammondii. General and Comparative Endocrinology 110 326-336.

Denver RJ $1998 b$ The molecular basis of thyroid hormone-dependent central nervous system remodeling during amphibian metamorphosis. Comparative Biochemistry and Physiology C. Pharmacology, Toxicology and Endocrinology 119 219-228.

Denver RJ \& Licht P 1988 Thyroid status influences in vitro thyrotropin and growth-hormone responses to thyrotropin-releasing-hormone by pituitary-glands of hatchling slider turtles (Pseudemys scripta elegans). Journal of Experimental Zoology 246293.

Denver RJ, Pavgi S \& Shi YB 1997 Thyroid hormone-dependent gene expression program for Xenopus neural development. Journal of Biological Chemistry 272 8179-8188.

Denver RJ, Boorse GC \& Glennemeier KA 2002 Endocrinology of complex life cycles: Amphibians. In Hormones, Brain and Behavior, pp 469-513. Eds D Pfaff, A Arnold, A Etgen, S Fahrbach, R Moss \& R Rubin. San Diego, CA: Academic Press, Inc.

Eliceiri BP \& Brown DD 1994 Quantitation of endogenous thyroid hormone receptors alpha and beta during embryogenesis and metamorphosis in Xenopus laevis. Journal of Biological Chemistry 269 24459-24465.

Forrest D 1994 The erbA thyroid hormone receptor genes in development of the central nervous system. Seminars in Cancer Biology 5 167-176.

Furlow JD \& Brown DD 1999 In vitro and in vivo analysis of the regulation of a transcription factor gene by thyroid hormone during Xenopus laevis metamorphosis. Molecular Endocrinology 13 2076-2089.
Galton V 1990 Mechanisms underlying the acceleration of thyroid hormone-induced tadpole metamorphosis by corticosterone. Endocrinology 127 2997-3002.

Gao XM, Kalkhoven E, Petersonmaduro J, Vanderburg B \& Destree O 1994 Expression of the glucocorticoid receptor gene is regulated during early embryogenesis of Xenopus laevis. Biochimica et Biophysica Acta 1218 194-198.

Glennemeier KA \& Denver RJ 2002 Developmental changes in interrenal responsiveness in anuran amphibians. Integrative and Comparative Biology 42 565-573.

Hagley RD \& Watlington CO 1996 Down-regulation of the mineralocorticoid receptor by dexamethasone in an amphibian kidney cell line (A6). Endocrine Research 22 221-235.

Hayes TB 1997 Steroids as potential modulators of thyroid hormone activity in anuran metamorphosis. American Zoologist 37 185-194.

Hayes TB \& Wu TH 1995 Interdependence of corticosterone hormones and thyroid hormones in toad larvae (Bufo boreas) 2. Regulation of corticosterone hormones and thyroid hormones. Journal of Experimental Zoology 271 103-111.

Jaffe RC 1981 Plasma concentration of corticosterone during Rana catesbeiana tadpole metamorphosis. General and Comparative Endocrinology 44 314-318.

Jolivet-Jaudet G \& Leloup-Hatey J 1984 Variations in aldosterone and corticosterone plasma levels during metamorphosis in Xenopus laevis tadpoles. General and Comparative Endocrinology 56 59-65.

Kanamori A \& Brown DD 1992 The regulation of thyroid hormone receptor beta genes by thyroid hormone in Xenopus laevis. Journal of Biological Chemistry 267 739-745.

Kawahara A, Baker B \& Tata JR 1991 Developmental and regional expression of thyroid hormone receptor genes during Xenopus metamorphosis. Development 112 933-943.

Kikuyama S, Suzuki MR \& Iwamuro S 1986 Elevation of plasma aldosterone levels of tadpoles at metamorphic climax. General and Comparative Endocrinology 63 186-190.

Kikuyama S, Kawamura K, Tanaka S \& Yamamoto K 1993 Aspects of amphibian metamorphosis: hormonal control. International Review of Cytology 145 105-148.

Kloas W, Reinecke M \& Hanke W 1997 Stage-dependent changes in adrenal steroids and catecholamines during development in Xenopus laevis. General and Comparative Endocrinology 108 416-426.

Krug EC, Honn KV, Battista J \& Nicoll CS 1983 Corticosteroids in serum of Rana catesbeiana during development and metamorphosis. General and Comparative Endocrinology 52 232-241.

Leloup J \& Buscaglia M 1977 Triiodothyronine, hormone of amphibian metamorphosis. Comptes Rendus Hebdomadaires des Séances de l'Académie des Sciences Serie D 284 2261-2263.

Leloup-Hatey J, Baloche S \& Jolivet-Jaudet G 1988 Variations des concentrations en corticosterone et en aldosterone dans divers tissus $\mathrm{du}$ tetard de Xenopus laevis pendant la metamorphose. Comptes Rendus des Séances de la Société de Biologie 182 354-360.

Licht P, McCreery BR, Barnes R \& Pang R 1983 Seasonal and stress related changes in plasma gonadotropins, sex steroids, and corticosterone in the bullfrog, Rana catesbeiana. General and Comparative Endocrinology 50 124-145.

Mackenzie DS, Licht P \& Papkoff H 1978 Thyrotropin from amphibian (Rana catesbeiana) pituitaries and evidence for heterothyrotropic activity of bullfrog luteinizing hormone in reptiles. General and Comparative Endocrinology 36 566-574.

Mangelsdorf DJ, Thummel C, Beato M, Herrlick P, Schutz G, Umesono K, Blumberg B, Kastner P, Mark M, Chambon P et al. 1995 The nuclear receptor superfamily. The second decade. Cell 83 835-839.

Mondou PM \& Kaltenbach JC 1979 Thyroxine concentrations in blood serum and pericardial fluid of metamorphosing tadpoles and of adult frogs. General and Comparative Endocrinology 39 343-349.

Nieuwkoop PD \& Faber J 1956 Normal table of Xenopus laevis Daudin. Amsterdam: North Holland Publishers. 
Niinuma K, Tagawa M, Hirano T \& Kikuyama S 1991 Changes in tissue concentrations of thyroid hormones in metamorphosing toad larvae. Zoological Science 8 345-350.

Niki K, Yoshizato K \& Kikuyama S 1981 Augmentation of nuclear binding capacity for triiodothyronine by aldosterone in tadpole tail. Proceedings of the Japan Academy Series B. Physical and Biological Sciences $\mathbf{5 7}$ 271-275.

Regard E, Taurog A \& Nakashima T 1978 Plasma thyroxine and triiodothyronine levels in spontaneously metamorphosing Rana catesbeiana tadpoles and in adult anuran amphibia. Endocrinology 102 674-684.

Schmidt TJ \& Meyer AS 1994 Autoregulation of corticosteroid receptors - how, when, where, and why. Receptor 4 229-257.

Shi YB 2000 Amphibian Metamorphosis. From Morphology to Molecular Biology. New York: Wiley-Liss.

Shi YB \& Brown DD 1993 The earliest changes in gene expression in tadpole intestine induced by thyroid hormone. Journal of Biological Chemistry 268 20312-20317.

Shi YB \& Liang VC 1994 Cloning and characterization of the ribosomal protein L8 gene from Xenopus laevis. Biochimica et Biophysica Acta 1217 227-228.

Spindler B \& Verrey F 1999 Aldosterone action: induction of $\mathrm{p} 21^{\text {ras }}$ and fra-2 and transcription-independent decrease in $m \gamma c$, jun and fos. American Journal of Physiology 276 C1154-C1161.

Suzuki MR \& Kikuyama S 1983a Corticoids augment nuclear binding capacity for triiodothyronine in bullfrog tadpole tail fins. General and Comparative Endocrinology $\mathbf{5 2}$ 272-278.

Suzuki RM \& Kikuyama S 1983 b Corticoids augment nuclear binding capacity for triiodothyronine in bullfrog tadpole tail fins. General and Comparative Endocrinology 52 272-278.
Tata JR 1993 Gene expression during metamorphosis - an ideal model for postembryonic development. Bioessays 15 239-248.

Tata JR 1994 Autoregulation and crossregulation of nuclear receptor genes. Trends in Endocrinology and Metabolism 5 283-290.

Tata JR, Baker BS, Machuca I, Rabelo EM \& Yamauchi K 1993 Autoinduction of nuclear receptor genes and its significance. Journal of Steroid Biochemistry and Molecular Biology 46 105-119.

Ulisse S \& Tata JR 1994 Thyroid hormone and glucocorticoid independently regulate the expression of estrogen receptor in male Xenopus liver cells. Molecular and Cellular Endocrinology 105 45-53.

Weber GM, Farrar ES, Tom CKF \& Grau EG 1994 Changes in whole body thyroxine and triiodothyronine concentrations and total content during early development and metamorphosis of the toad Bufo marinus. General and Comparative Endocrinology 94 62-71.

Weil MR 1986 Changes in plasma thyroxine levels during and after spontaneous metamorphosis in a natural population of the Green Frog, Rana clamitans. General and Comparative Endocrinology 62 8-12.

Wong J \& Shi YB 1995 Coordinated regulation of and transcriptional activation by Xenopus thyroid hormone and retinoid $\mathrm{X}$ receptors. Journal of Biological Chemistry 270 18479-18483.

Yaoita Y \& Brown DD 1990 A correlation of thyroid hormone receptor gene expression with amphibian metamorphosis. Genes and Development 4 1917-1924.

Received in final form 26 November 2003

Accepted 24 December 2003

Made available online as an

Accepted Preprint 15 January 2004 